\title{
C-erbB2/neu Transfection Induces Gap Junctional Communication Incompetence in Glial Cells
}

\author{
Andreas Hofer, ${ }^{1}$ Juan C. Sáez, ${ }^{2}$ Chia Cheng Chang, ${ }^{3}$ James E. Trosko, ${ }^{3}$ David C. Spray, ${ }^{4}$ and \\ Rolf Dermietzel ${ }^{1}$ \\ 1/nstitute of Anatomy, University of Regensburg, 93053 Regensburg, Germany, 2Departamento de Ciencias Fisiologicas, \\ Facultad de Ciences Biologicas, Pontificia Universidad Catholica de Chile, Santiago, Chile, ${ }^{3}$ Department of Pediatrics and \\ Human Development, Michigan State University, East Lansing, Michigan 48824, and ${ }^{4}$ Albert Einstein College of Medicine, \\ Department of Neuroscience, New York, New York 10461
}

Astrocytes form functional networks that participate in active signaling in which external stimuli are generated and amplified in many of the same ways as in neurons. Gap junctions between astrocytes offer the structural avenue by which the electrical and metabolic signals are propagated from one cell to another. Little is known about the trafficking, assembly, and degradation mechanisms of the major astrocytic gap junction protein connexin43. We have studied a glial cell line transfected with the $\mathrm{C}$-erbB2/neu oncogene $\left(\mathrm{neu}^{+}\right)$, finding severe interruption of gap junctional communication after stable transfection. Evidence from Western blotting and phosphorylation studies showed that the processing of connexin43 to its higher phos- phorylated isoforms is disturbed. Confocal laser imaging indicates that the major deficit in the $\mathrm{neu}^{+}$cells is attributable to a lack in plaque assembly of connexin43. Because the $n e u^{+}$cells also lack N-CAM proteins and because work from others has indicated a close relationship between communication competence and constitutive CAM expression, our data suggest that expression of C-erbB2/neu oncogene alters cell-cell association via CAM proteins, which thereby affects gap junction plaque assembly and appropriate phosphorylation of connexin43.

Key words: gap junctions; astrocytes; oncogene; connexin43; phosphorylation; N-CAM
Gap junctions provide intercellular pathways for electrical and metabolic coupling between adjoining cells and are found in almost all tissues except for a few cell types, such as mature skeletal muscle cells and circulating blood cells. In the CNS, gap junctions have been found between neurons and various other cell types (for recent review, see Dermietzel and Spray, 1993), and it is generally well accepted that they constitute the structural link by which electrically and/or metabolically coupled compartments of the CNS are created. Gap junctions are composed of transmembrane channels that directly couple the cytoplasm of adjoining cells. The channels are composed of hemichannels (connexons) in one plasma membrane joined in mirror symmetry with a connexon in the adjacent cell (Caspar et al., 1977; Makowski et al., 1977). Each hemichannel is an oligomer of six protein subunits (connexins). Recent cloning works have elucidated that connexins form a protein family, the members of which show a highly diversified distribution among different cell types (Bennett et al., 1991; Beyer, 1993; Dermietzel and Spray, 1993). In the CNS, a cellspecific and developmentally regulated expression of three connexin isoforms has been demonstrated (Dermietzel et al., 1989). Via the molecular characterization of the connexin protein family and the subsequent generation of specific probes, i.e., isotypic

Received Dec. 18, 1995; revised April 26, 1996; accepted April 29, 1996.

This work was funded by grants from the Deutsche Forschungsgemeinschaft (Schwerpunkt Glia to R.D.) as well by a Fondecyt Grant 1930690 (J.C.S.), National Institutes of Health Grant GM-30667 FIRCA (E. L. Hertzberg and J.C.S.), NCI Grant CA 21104 (J.E.T.), and National Institutes of Health (NS34931) and Muscular Dystrophy Association Grants (D.C.S.). The anti-Cx43 antibody to peptide 346-360 used for phospho amino acid analysis was kindly provided by Dr. E. L. Hertzberg, Albert Einstein College of Medicine.

Correspondence should be addressed to Rolf Dermietzel, Institute of Anatomy, University of Regensburg, 93053 Regensburg, University Street 31, Germany.

Copyright (C) 1996 Society for Neuroscience $0270-6474 / 96 / 164311-11 \$ 05.00 / 0$ antibodies, cDNAs etc., it has become feasible to better address the issue of occurrence and the potential importance of electrotonic transmission in mammalian brain and spinal cord. Astrocytes present one cell type in which these issues can now be addressed, because a detailed characterization of the major astrocytic connexin type and its functional properties recently has been achieved (Dermietzel et al., 1991; Giaume et al., 1991a).

Astrocytes form an extensively coupled syncytium, which is assumed to play a crucial role in the homeostatic balance of the interstitial cerebral fluid. A variety of regulatory mechanisms have been assigned to astrocytes in which the presence of intercellular coupling is essential. A prominent feature is the uptake and buffering of $\mathrm{K}^{+}$surrounding active neurons. Gap junctions may provide a direct pathway from the site of potassium disposal to the perivascular compartment or, alternatively, may increase the volume of the astrocytic buffer sink by connecting multiple cytoplasmic units (Kuffler et al., 1966; Orkand et al., 1966; GardnerMelvin, 1983; Newman, 1986; Walz, 1989). Another feature of considerable functional significance is the ability of astrocytes to create spontaneous $\mathrm{Ca}^{2+}$ waves after topical glutamate application or mechanical stimulation (Cornell-Bell et al., 1990; Finkbeiner, 1992). Such transjunctional oscillatory $\mathrm{Ca}^{2+}$ signaling provides the possibility of a dynamic population response in an electrically coupled astrocytic network. The demonstration that astrocytes possess neurotransmitter receptors in culture and in slice preparations has been taken as a strong indication that astrocytes participate in active signaling in which external stimuli are generated and amplified as in neurons (Barres et al., 1990; Parpura et al., 1994). In all likelihood, astrocytic gap junctions offer the structural avenue by which the electrical and metabolic signals are mediated (Dermietzel and Spray, 1993). 
Very little is known about the molecular mechanisms that regulate the coupling efficiency between astrocytes. In a recent series of experiments on sarcoma cell lines, Musil et al. (1990) showed that cell adhesion is an important prerequisite for connexin43 (Cx43) insertion into the plasma membrane. In addition, they provided evidence that post-translational phosphorylation of Cx43 is an important event in gap junction formation and/or activation. Communication incompetence can also be obtained by transfection of cell lines with various viral oncogenes (Azarnia and Loewenstein, 1987; Bignami et al., 1988; Dotto et al., 1989; Martin et al., 1991). For the $s r c$ oncogene product pp $60^{\mathrm{v}-\mathrm{src}}$, phosphorylation of $\mathrm{Cx} 43$ at tyrosine 265 has been shown to be responsible for the communication deficiency (Swenson et al., 1990). From these studies, it seems reasonable to expect that similar mechanisms may be influential on interglial coupling. We therefore transfected a communication-competent glial cell line with the rat C-erbB2/neu oncogene $\left(\right.$ neu $\left.^{+}\right)$, which encodes a $185 \mathrm{kDa}$ transmembrane protein with intrinsic tyrosine kinase activity, and which exhibits extensive structural homology with the epidermal growth factor receptor (Coussens et al., 1985; Bargmann et al., 1986a,b). We found that transfection of the glial cell line resulted in a significant reduction of cell-cell communication. In contrast to the effect reported for the $v$-src gene product, we did not detect phosphorylation at the tyrosine sites; rather, we found a remarkable reduction of the higher molecular weight isoforms of Cx43 that are believed to arise from phosphorylation of serine/ threonine residues. In addition, the C-erbB2/neu oncogene transfection also resulted in a loss of expression of the cell adhesion molecule N-CAM, which might largely explain the reduced gap junctional communication.

\section{MATERIALS AND METHODS}

Cultures of purified astrocytes and rat glial cells. Cultures of purified astrocytes were obtained as described (Dermietzel et al., 1991) and cultured for $12 \mathrm{~d}$. A wild-type Sprague-Dawley rat glial cell line (gift from Dr. A. Koestner, Michigan State University) has been previously reported to be well coupled under subconfluent conditions (Suter et al., 1987).

Growth media. Cultures of purified astrocytes were grown in a medium containing 45\% minimal essential medium (MEM), 45\% Ham's F12, $10 \%$ fetal calf serum, penicillin $(50 \mu \mathrm{g} / \mathrm{ml})$, streptomycin $(50 \mathrm{mg} / \mathrm{ml})$, and $2 \mathrm{~mm}$ glutamate, buffered with $25 \mathrm{~mm}$ bicarbonate. The rat glial cell line was grown in MEM supplemented with $1 \mathrm{~mm}$ sodium pyruvate, $0.05 \%$ nonessential amino acids (Biochrom, Berlin, Germany), $0.1 \mathrm{mg} / \mathrm{ml}$ gentamycin, and $10 \%$ fetal calf serum, buffered with $25 \mathrm{~mm}$ bicarbonate. Medium for culturing the C-erbB2/neu transformed rat glial cell line contained $0.05 \mathrm{mg} / \mathrm{ml} \mathrm{G} 418$ as an additive. All cultures were grown at $37^{\circ} \mathrm{C}$ in $5 \%$ $\mathrm{CO}_{2}, 95 \%$ air atmosphere in humidified water-jacketed incubators.

Transfection and subculture. The C-erbB2/neu transforming oncogene, with a substitution mutating valine to glutamic acid at residue 664, was derived originally from DNA of ethylnitrosourea-induced rat glioblastomas. The neu proto-oncogene ( $t r^{-}$, with val 664) and its neu transforming oncogene ( $\mathrm{rr}^{+}$, with glu 664) were inserted into the SalI cloning site of a modified version of pDOL retrovirus vector, containing the selectable G418 neomycin-resistance marker. As a control, cells were infected by a virus with neomycin resistance only.

For transfection of subconfluent rat glial cells, undiluted viral supernatant (containing $1 \times 10^{6}$ cells $/ \mathrm{ml}$ ) was added separately with $8 \mu \mathrm{g} / \mathrm{ml}$ polybrene for $2 \mathrm{hr}$ at $34^{\circ} \mathrm{C}$. Resistant cells were selected in medium containing 0.5 $\mathrm{mg} / \mathrm{ml} \mathrm{G} 4182 \mathrm{~d}$ after viral infection and allowed to continue to grow for $7 \mathrm{~d}$. For this study, the clone (GN-7) that stably transfected with the transforming oncogene (designated $\mathrm{neu}^{+}$) was compared with parental wild-type cells (designated $\mathrm{neu}^{-}$) transfected with the virus containing the neomycinresistant marker but not the nеu insert (here designated nеo). In addition, clones overexpressing the neu proto-oncogene $\left(t r^{-}\right)$were screened for phenotypical appearance and dye transfer.

Immunofluorescence. Processing for immunofluorescence of $\mathrm{Cx} 43$, $\mathrm{N}-\mathrm{CAM}$, and glial fibrillary acidic protein (GFAP) was performed as described (Dermietzel et al., 1984). Briefly, cells were fixed in absolute ethanol at $-20^{\circ} \mathrm{C}$. After washing twice with PBS (10 mM phosphate buffer, $\mathrm{pH} 7.5,140 \mathrm{mM} \mathrm{NaCl}$ ), cells were incubated in PBS supplemented with $10 \%$ horse serum and $1 \%$ bovine serum albumin (BSA) to block nonspecific labeling. The primary antibody was applied for $60 \mathrm{~min}$ at room temperature, removed by three washes with PBS supplemented with $1 \% \mathrm{BSA}$, and followed by incubation with the secondary fluorescein isothiocyanate (FITC)-labeled antibody (Sigma, Munich, Germany).

Northern blots and in situ hybridization. Isolation and Northern blots of total RNA were performed according to standard procedures (Sambrook et al., 1989) with the following modifications: total RNA of subconfluent cultures was extracted with $4 \mathrm{~m}$ guanidinium thiocyanate, $25 \mathrm{~mm}$ sodium acetate, $\mathrm{pH} 6.0,1 \%$ mercaptoethanol followed by centrifugation at 100,000 $\mathrm{g}$ (rotor: Sorvall TH-641) in $5.7 \mathrm{M}$ caesium chloride solution buffered with $25 \mathrm{~mm}$ sodium acetate, $\mathrm{pH}$ 6.0. After phenol/chloroform extraction, the RNA was twice precipitated with ethanol and resuspended in water. Twenty micrograms total RNA was electrophoresed on $1.2 \%$ agarose gels containing $2.2 \mathrm{M}$ formaldehyde and transferred to nylon membranes by press blot. A $1.3 \mathrm{~kb}$ cDNA fragment of rat heart Cx43 (Beyer et al., 1987) was labeled with $\left[{ }^{32} \mathrm{P}\right]$ deoxycytosine triphosphate using the random priming reaction. Blots were hybridized at $42^{\circ} \mathrm{C}$ overnight, washed for $2 \mathrm{hr}$ in $2 \times \mathrm{SSC}, 1 \% \mathrm{SDS}$ at $55^{\circ} \mathrm{C}$, followed by stringent washes for $2 \mathrm{hr}$ in $0.1 \times \mathrm{SSC}, 0.1 \%$ SDS at $62^{\circ} \mathrm{C}$. Blots were exposed to $\mathrm{X}$ OmAT AR 5 film (Eastman Kodak, Rochester, NY) at $-70^{\circ} \mathrm{C}$.

Subconfluent monolayers of $\mathrm{ne}^{-}$and $\mathrm{neu}^{+}$cells were grown on glass coverslips overnight and used for in situ hybridization as described (Dermietzel et al., 1992). Briefly, cells were rinsed in PBS and fixed four times repeatedly in $4 \%$ freshly prepared paraformaldehyde in PBS for $20 \mathrm{~min}$ at room temperature, followed by fixation in a solution of $25 \%$ acetic acid and $75 \%$ methanol at $-20^{\circ} \mathrm{C}$. Cells were washed three times with PBS and blocked three times for $10 \mathrm{~min}$ in $100 \mathrm{~mm}$ glycine in PBS. Monolayers were rinsed with $100 \mathrm{~mm}$ triethanolamine, $\mathrm{pH} 8.0$, and incubated in $100 \mathrm{~mm}$ triethanolamine, $\mathrm{pH} 8.0$, with acetic anhydride for $10 \mathrm{~min}$. Then they were rinsed in water, washed in $2 \times$ SSC for $5 \mathrm{~min}$ and immersed in $100 \%$ ethanol followed by ethanol air drying. Prehybridization was performed at $42^{\circ} \mathrm{C}$ for 4-5 hr in PHmix ( $2 \times$ SSC, $5 \times$ Denhardt's, Salmon Sperm DNA 1:20, $50 \%$ formaldehyde), followed by an additional wash in ethanol and air drying. The $1.3 \mathrm{~kb}$ fragment of $\mathrm{Cx} 43$ (see above) was labeled with digoxigenin (DIG) according to the manufacturer's recommendations (Boehringer Mannheim, Mannheim, Germany) and hybridized at $42^{\circ} \mathrm{C}$ for $15 \mathrm{hr}$ in Hmix ( $2 \times$ SSC, $5 \times$ Denhardt's, Salmon Sperm DNA 1:20, $10 \%$ dextran sulfate, $50 \%$ formaldehyde). Successively, cells were washed in $2 \times, 1 \times$, and $0.1 \times \mathrm{SSC}$ at $40^{\circ} \mathrm{C}$ and in $0.1 \times$ SSC and PBS at room temperature. In a final step, cells were blocked in $1 \%$ DIG-blocking reagent for 30 min, washed with PBS, and incubated with anti-DIG antibody labeled with alkaline phosphatase.

Subfractionation and Western blotting. $\mathrm{Neu}^{-}$, neo, and $\mathrm{neu}^{+}$cells were scraped with a rubber policeman, pelleted, and washed with ice-cold PBS. Homogenization was performed at $4^{\circ} \mathrm{C}$ in $10 \mathrm{~mm}$ potassium phosphate, pH 7.2, with $2 \mathrm{~mm}$ phenylmethylsulfonyl fluoride (PMSF) with a glass douncer (4 strokes). The homogenates were centrifuged at $160 \times g$ (Sigma 3K20, rotor 12154) for $2 \mathrm{~min}$ at $4^{\circ} \mathrm{C}$. The sediment was resuspended in $10 \mathrm{~mm}$ potassium phosphate, $\mathrm{pH} 7.2$, containing a crude fraction enriched with cell nuclei and unbroken cells. Supernatants were diluted in a 10-fold volume of $10 \mathrm{~mm}$ potassium phosphate, $\mathrm{pH} 7.2,2 \mathrm{~mm}$ PMSF, and centrifuged at $10,000 \times g($ Sigma $3 \mathrm{~K} 20$, rotor 12158$)$ at $4^{\circ} \mathrm{C}$ for $10 \mathrm{~min}$ to yield plasma membrane and mitochondrial fraction (crude membrane fraction). Microsomal fractions were obtained after centrifugation of the $10,000 \mathrm{~g}$ supernatant at $100,000 \times g$ (Sorvall OTD 65 , rotor TH641) for $1 \mathrm{hr}$ at $4^{\circ} \mathrm{C}$. The supernatants containing the cytosol were precipitated with $20 \%$ trichloroacetic acid. The concentration of protein in cell subfractions was determined using the enhanced alkaline copper protein assay (Lowry et al., 1951) with BSA as a standard.

Proteins of cell subfractions and total homogenate were resolved by electrophoresis on $15 \%$ polyacrylamide gels (Laemmli, 1970) and electroblotted with a wet blotting system (Hoefer, San Francisco). Blotted nitrocellulose was blocked in 5\% dry milk and probed with site-specific antibodies against $\mathrm{Cx} 43$ or N-CAM (see Monoclonal and polyclonal antibodies). A gold-conjugated anti-rabbit IgG served as secondary antibody after an additional incubation for $1 \mathrm{hr}$ and was visualized by silver enhancement according to the manufacturer's recommendations (Amersham, Buckinghamshire, UK).

Immunoprecipitation and half-time measurement. $\mathrm{Neu}^{-}$and $\mathrm{neu}^{+}$cells were seeded at $2.5 \times 10^{5}$ cells $/ \mathrm{ml}$ in $20 \mathrm{~mm}$ culture dishes. Three days after replating, the medium was replaced by a deficient medium containing $90 \%$ of MEM Eagle's Medium (Sigma) supplemented with $1 \mathrm{~mm}$ sodium pyruvate, $0.05 \%$ nonessential amino acids, $0.1 \mathrm{mg} / \mathrm{ml}$ gentamycin, 

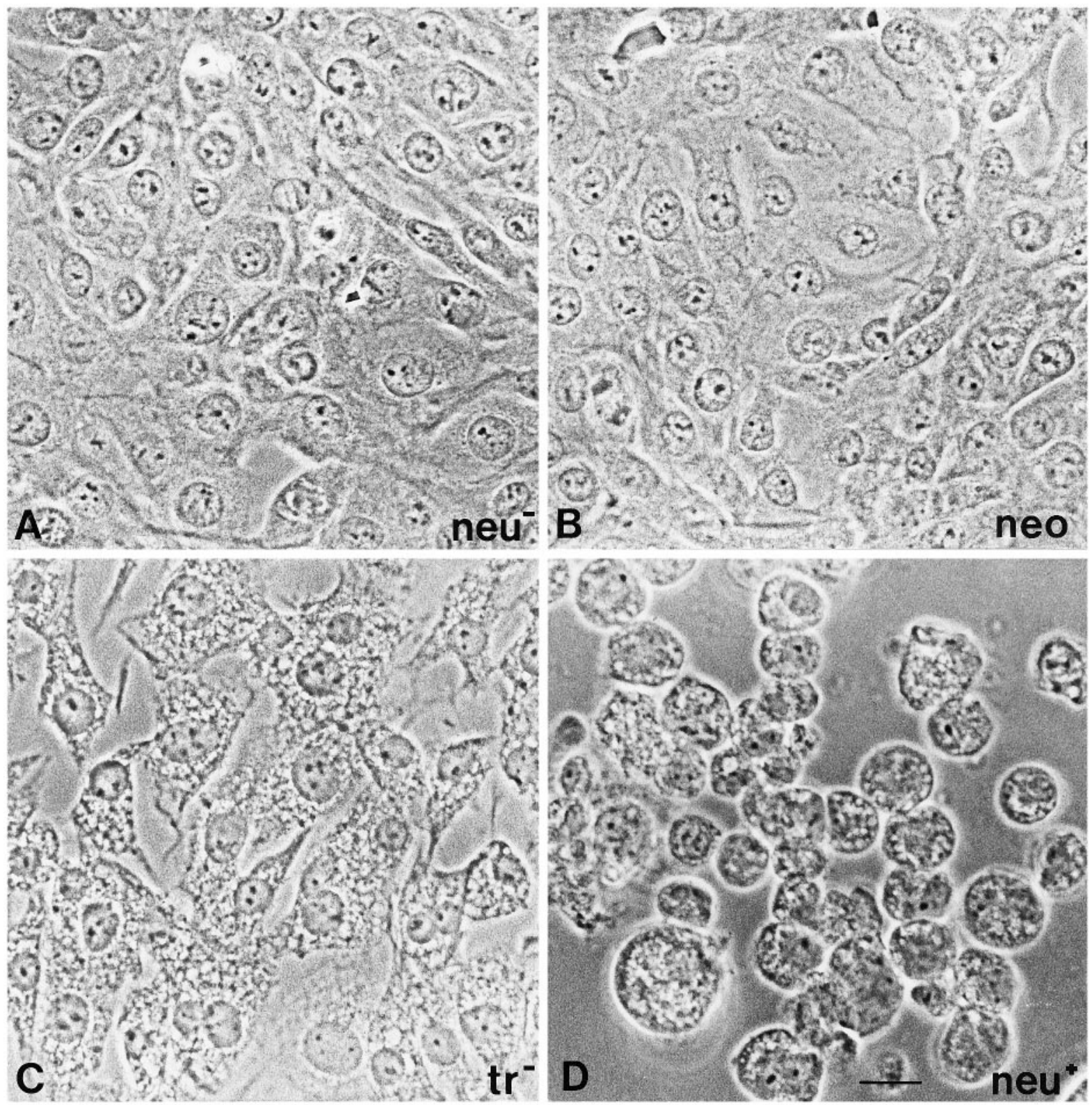

Figure 1. Phenotypic appearance of untransfected and transfected glial cells. $A$, Parental glial cells (neu ${ }^{-}$) reveal a flat adherent phenotype as is the case for neo $(B)$ and proto-oncogene $(C)$-transfected cells. After transfection with the transforming oncogene $\left(n e u^{+}\right)$, cells appear less adherent and rounder (D). Scale bar, $20 \mu \mathrm{m}$.

buffered with $25 \mathrm{~mm}$ bicarbonate and $10 \%$ of normally used medium as described above. Cells were labeled with $3.7-4.4 \mathrm{MBq} / \mathrm{ml}$ of $\mathrm{L}-\left[{ }^{35} \mathrm{~S}\right] \mathrm{methionine}$ or with $5.5-11.8 \mathrm{MBq} / \mathrm{ml}\left[{ }^{32} \mathrm{P}\right]$ orthophosphate for $3 \mathrm{hr}$. Cells were rinsed three times with growth medium and chased for various time intervals $(1,2,3,5$, and $8 \mathrm{hr}$, respectively) until further processing.

Cells were treated and lysed according to the method described elsewhere (Musil et al., 1990). The lysate was then precleared for $30 \mathrm{~min}$ at $4^{\circ} \mathrm{C}$ with Protein A bound to Sepharose CL-4B. The immunoprecipitation was performed with 1.8-3.5 $\mu \mathrm{g}$ of affinity-purified anti-Cx43 antibody (pAb2, see Monoclonal and polyclonal antibodies) at $4^{\circ} \mathrm{C}$ for $4 \mathrm{hr}$. The antigen-antibody complexes were collected by the addition of $10 \mu \mathrm{l}$ of Protein A Sepharose CL-4B for $40 \mathrm{~min}$ and processed according to the method described (Musil et al., 1990). The immunoprecipitates were analyzed on SDS-PAGE using a $10 \%$ acrylamide $/ 0.27 \%$ bisacrylamide system (Laemmli, 1970). The gels were fixed in $40 \%$ methanol $10 \%$ acetic acid for 30 min. Gels with $\mathrm{L}-\left[{ }^{35}\right.$ S $]$ methionine-labeled samples were soaked in Amplify (Amersham) for 40 min. Gels were dried and exposed to XOmAT AR 5 film (Eastman Kodak) with an intensifying screen at $-80^{\circ} \mathrm{C}$.

Phosphoamino acid analysis. Phosphoamino acid analysis was per- formed as described (Sáez et al., 1990). ${ }^{32} \mathrm{P}$-labeled protein bands were excised from dried polyacrylamide gels using the autoradiography as a guide. Gel slices were rehydrated and subjected to trypsin digestion. The digests were lyophilized and then hydrolysed with $6 \mathrm{M} \mathrm{HCl}$ for 45-60 min at $110^{\circ} \mathrm{C}$ in a $\mathrm{N}_{2}$ environment. Phosphoamino acids were separated by two steps: one-dimensional electrophoresis at $\mathrm{pH} 1.9 \mathrm{in} 8.7 \%$ acetic acid $/ 2.5 \%$ formic acid, followed by electrophoresis in the same direction at $\mathrm{pH} 3.5$ in $10 \%$ acetic acid $/ 1 \%$ pyridine. Phosphoamino acids were detected by autoradiography and identified by the specific mobilities of the P-Ser, $\mathrm{P}-\mathrm{Thr}$, and P-Tyr standards after developing with $0.1 \%$ ninhydrine.

Lucifer yellow injection and $\mathrm{Ca}^{2+}$ imaging. For dye-coupling assays, one cell was injected with Lucifer yellow $(4 \%$ in $150 \mathrm{~mm} \mathrm{LiCl})$ iontophoretically, and cells were viewed on a Zeiss Axiovert microscope (Thornwood, NY) equipped with fluorescence illumination and FITC filters.

For $\mathrm{Ca}^{2+}$ imaging, neu ${ }^{-}$, neo, and $n e u^{+}$cells were seeded onto glass coverslips at $1 \times 10^{5}$ cells $/ \mathrm{ml}$. After $3 \mathrm{~d}$, cells were washed three times with immersion (IM) buffer containing (in mM) 10 HEPES, $131 \mathrm{NaCl}, 5$ $\mathrm{KCl}, 4 \mathrm{CaCl}_{2}$, and 25 glucose and incubated in $16 \mu \mathrm{M}$ Fura-2 AM for 30 min at $37^{\circ} \mathrm{C}$ in a humidified incubator. Loaded cells were washed three 

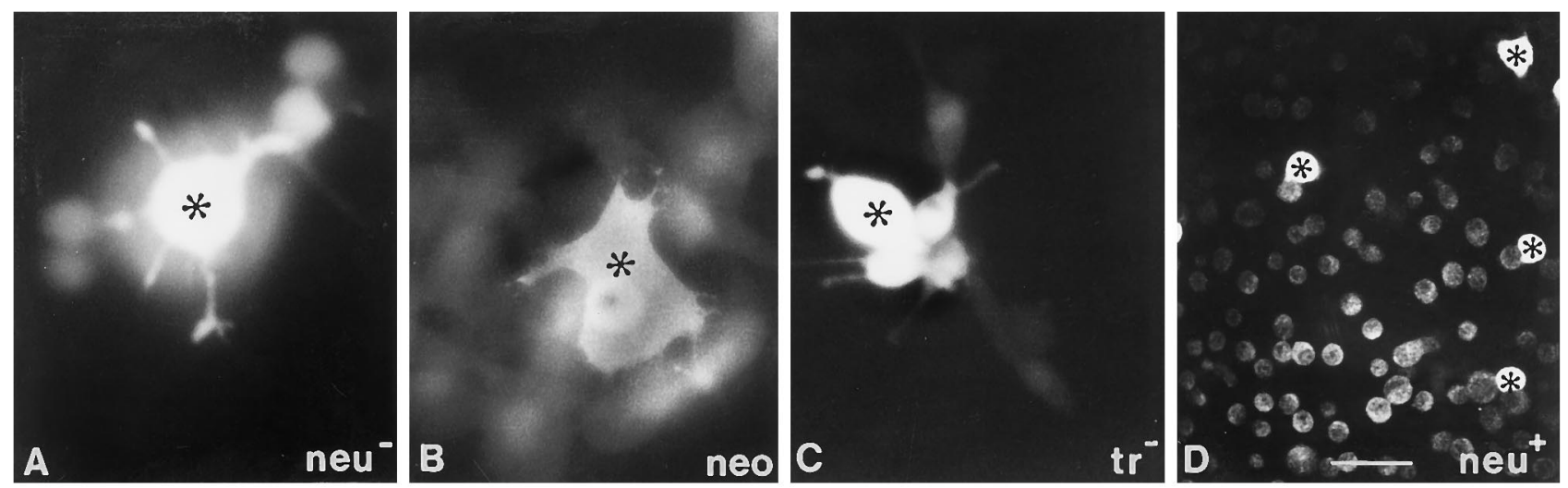

Figure 2. Loss of communication after transfection of rat glial cells with the C-erbB2/neu oncogene. Microinjection of Lucifer yellow indicates extensive dye coupling in $\mathrm{neu}^{-}(A)$, neo $(B)$, and proto-oncogene-transfected cells $(C)$. Neu ${ }^{+}$cells $(D)$ revealed no dye transfer between neighboring cells. The injected cells are marked with asterisks. See Table 1 for quantification. Scale bars: $20 \mu \mathrm{m}$ in $A-C ; 40 \mu \mathrm{m}$ in $D$.

times with IM-buffer before use. For testing gap junctional intercellular coupling, cells were microinjected with $1 \mathrm{mM} \mathrm{Ca}^{2+}$ iontophoretically. Analysis of calcium spread was performed with a $\mathrm{Ca}^{2+}$ imaging system (Technology Transfer, Martinsried, Germany). Excitation wavelengths ( 340 and $380 \mathrm{~nm}$ ) were alternately selected by a monochromator, and the shutter driver (model D122, Uni Blitz) was illuminated for 400 and 250 msec, respectively. $\mathrm{Ca}^{2+}$ images were captured using a silicon-intensified target camera at $450 \mathrm{~nm}$ emission and were analyzed by Fucal 2.0 software (Technology Transfer). Calibration of dual wavelength fluorescence data using values obtained in free solutions was performed as described (Thomas and Dellaville, 1991).

Monoclonal and polyclonal antibodies. Several distinct anti-Cx43 antibodies were used in this study. Two rabbit antisera generated against Cx43 peptide sites were used: the antibodies are directed to position 346-360 (pAb1; see Dermietzel et al., 1989) and position 359-381 (pAb2). Affinity purification of pAb2 was obtained using the oligopeptides as ligands. No immunoreactivity to the carrier proteins (ovalbumin) was detectable by Western blotting after purification. Specific reaction of pAb2 for $\mathrm{Cx} 43$ was proven by immunofluorescence and Western blotting. A polyclonal rabbit antiserum specific for N-CAM was used for immunofluorescence and Western blotting (gift from Dr. M. Schachner, Zürich, Switzerland). Cell cultures were tested for GFAP immunoreactivity with an anti-GFAP rabbit antibody (Sigma) to check for astrocytic features of cultured $n e u^{-}$and $n e u^{+}$cells, respectively. Successful transfection with the $\mathrm{C}$-erbB/2 oncogene was detected with a monoclonal antiphosphotyrosine antibody (Upstate Biotechnology, Lake Placid, NY).

\section{RESULTS}

\section{C-erbB2/neu transfection results in a communication deficiency in glial wild-type cells}

The morphology of the $n e u^{-}$cells was indistinguishable from that of cells transfected with vector carrying the neomycin resistance marker (neo4) or with the nontransforming version of the C-erB2/ neu oncogene $\left(\mathrm{tr}^{-}\right)$. Their typical appearance was in the form of flat cells with filopodia resembling the configuration of primary cultured astrocytes (Fig. 1A-C). Successful transfection with the transforming oncogene $\left(\mathrm{tr}^{+}\right)$resulted in a remarkable change in phenotypic appearance of the $n e u^{+}$cells, assuming round shapes and growing in foci (Fig. 1D). Staining with a monoclonal antiphosphotyrosine antibody revealed significant increase of phosphotyrosine proteins in $\mathrm{neu}^{+}$cells compared with the $n e u^{-}$and neo cells. Cells transfected with the nontransforming version of the oncogene showed variable staining levels, indicating inconsistent overexpression of the proto-oncogene (data not shown).

We then determined coupling efficiency in nontransformed and transformed cell lines by intracellular injections of Lucifer yellow into subconfluent and confluent cells. Whereas extensive dye spread occurred in the neu $u^{-}$cells [the neo cells and the $\mathrm{tr}^{-}$cells reaching third-order cells within minutes (Fig. 2A,B,C)], the $n e u^{+}$ cells showed significantly reduced dye transfer even after excessive duration times ( $>15$ min; Fig. $2 C$, Table 1$)$.

In addition to the dye-transfer experiments, we performed ratiometric imaging of $\mathrm{Ca}^{2+}$ after intracellular calcium injection. This technique offers the advantage of exploiting a physiological indicator for the detection of effective cell coupling (Sáez et al., 1989). Intracellular $\mathrm{Ca}^{2+}$ levels were measured in Fura-2-loaded $n e u^{-}, n e o$, and $n e u^{+}$cells beginning $45 \mathrm{sec}$ after calcium injection. The basal levels of free calcium were $40 \mathrm{~nm}$ in all three cell lines. Microinjection of a $10 \mu \mathrm{M} \mathrm{Ca}{ }^{2+}$ into a single cell led to rapid elevation of $\mathrm{Ca}^{2+}$ in second- and third-order cells within seconds in $n e u^{-}$cells (Fig. 3A-H). Calcium levels revealed an increase in neighboring neu ${ }^{-}$(Fig. 3a) and neo cells (Fig. 3b) to 500-700 nм and partially recovered within $<60 \mathrm{sec}$ to basal levels.

$\mathrm{Neu}^{+}$cells behaved entirely differently. First, transfer was entirely random, leaving some first-order cells completely excluded from the $\mathrm{Ca}^{2+}$ increase (Fig. $3 A^{\prime}-H^{\prime}$ ). Second, there was a considerable time lag in $\mathrm{Ca}^{2+}$ transfer compared with the $n e u^{-}$and neo cells (Fig. $3 c$ ). The dye injection and the calcium-imaging studies document a significant coupling deficiency of the $n e u^{+}$ cells. One reasonable explanation for this deficiency in coupling could be the loss of connexin expression after the transfection. We therefore examined these cells for the presence of $\mathrm{Cx} 43$ mRNA and protein, which constitutes the major connexin expressed in astrocytes (Dermietzel et al., 1991; Giaume et al., 1991a). Because no differences in the phenotypic appearance between $n e u^{-}$and neo cells and cells transfected with the proto-oncogene were evident, we continued further work with $\mathrm{neu}^{-}$and $\mathrm{neu}^{+}$cells exclusively.

\begin{tabular}{|c|c|c|}
\hline Cell type & No. of coupled cells ${ }^{a}$ & No. of uncoupled cells \\
\hline$n e u^{-}$ & $33 \pm 5$ & $7 \pm 4$ \\
\hline nеo (clone 1$)$ & $25 \pm 3$ & $3 \pm 2$ \\
\hline$n e u^{+}$(clone 7) & $2 \pm 2$ & 23 \\
\hline$t r^{-}$ & $27 \pm 6$ & $6 \pm 3$ \\
\hline
\end{tabular}

${ }^{a}$ Accumulated numbers of coupled first and higher-order cells from three different experiments. 

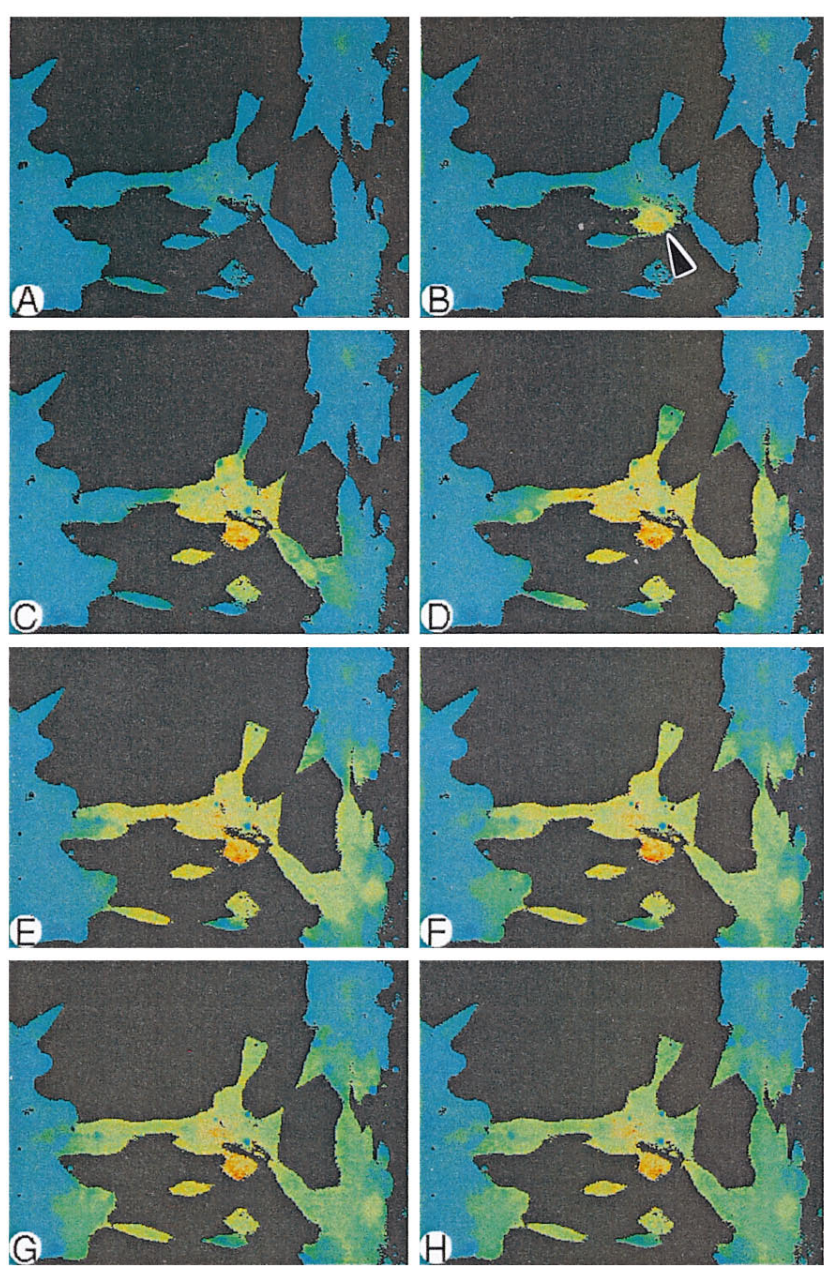

neu-

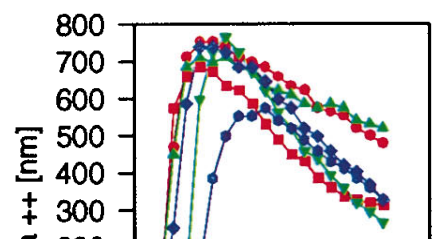

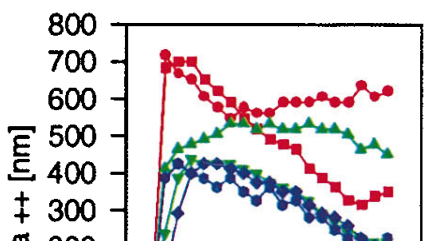
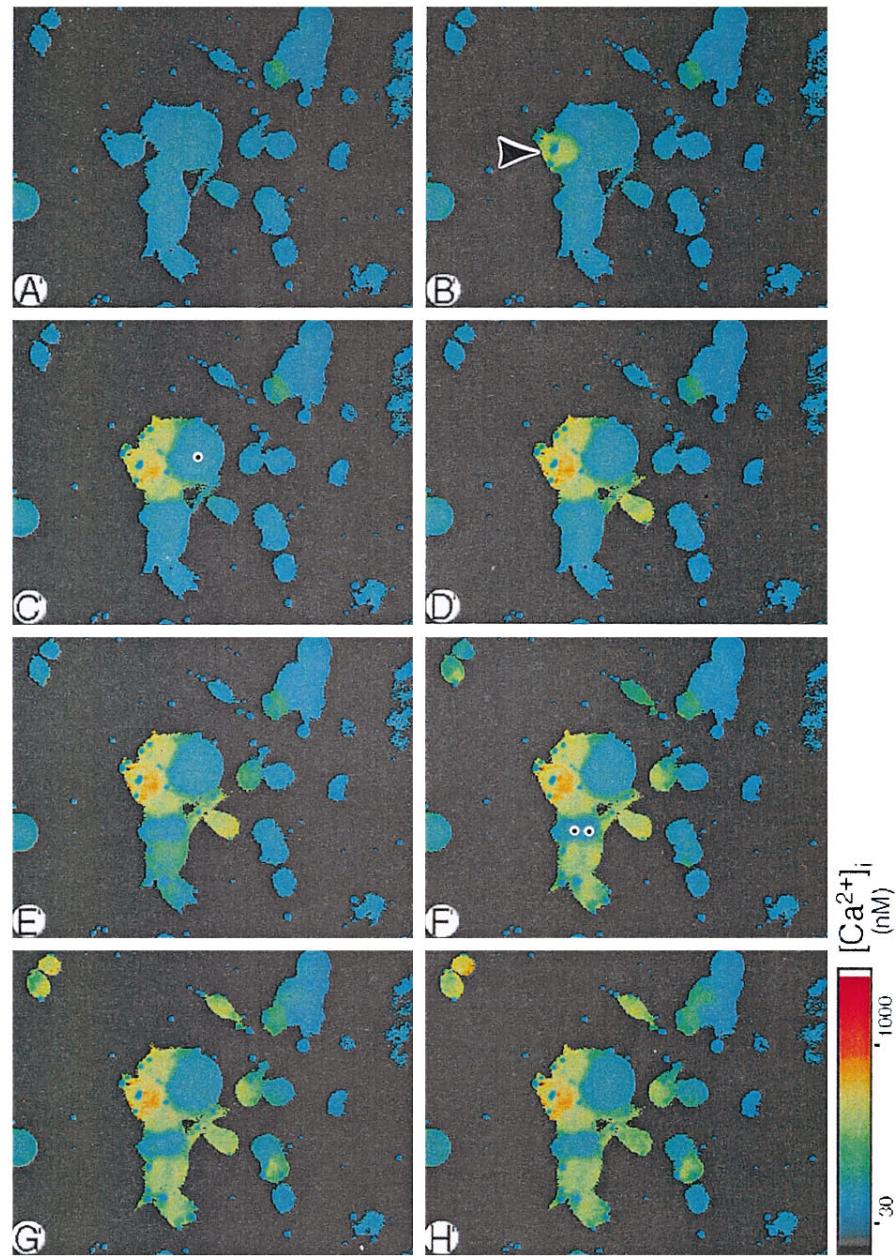

neu ${ }^{+}$

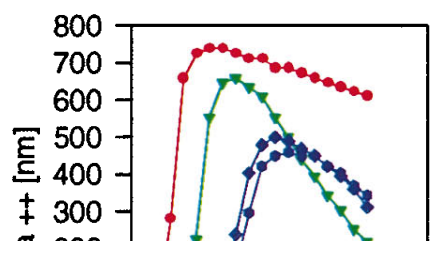

Figure 3. Junctional conductance between $n e u^{-}(A-H)$ and $n e u^{+}\left(A^{\prime}-H^{\prime}\right)$ cells as determined by $\mathrm{Ca}^{2+}$ spread. Ca ${ }^{2+}$ spread was initiated by intracellular microinjection of $1 \mu \mathrm{M} \mathrm{Ca}^{2+}$ solution. Injected cells are labeled by an arrow $\left(B, B^{\prime}\right)$. Note the radially symmetric spread of $\mathrm{Ca}^{2+}$ in the $n e u^{-}$cells and the chaotic distribution in the $n e u^{+}$cells, leaving first-order cells (dot in $\left.C^{\prime}\right)$ and higher-order cells (double dot in $F^{\prime}$ ) completely without invasion by the $\mathrm{Ca}^{2+}$ wave. Pseudocolored scale bar to the lower right indicates $\mathrm{Ca}^{2+}$ concentrations (in nM) after calibration of $\mathrm{Ca}^{2+}$ values in free solution. Graphs in $a-c$ show the time course of calcium spread in $\mathrm{neu}^{-}(a), n e o(b)$, and $n e u^{+}(c)$ cells. $\mathrm{Ca}^{2+}$ increase was monitored in regions of interest centered over individual cells. Each curve indicates the increase of $\mathrm{Ca}^{2+}$ in cells at different distances from the injected cell as a function of time. Red depicts first-order cells, blue second-order cells, and green higher-order cells. Note that in $n e u^{+}$cells $(c)$, a considerable time lag in $\mathrm{Ca}^{2+}$ spread occurs, and the cells respond asynchronously.

\section{The major effect of C-erbB2/neu transfection is reduction of the phosphorylated isoforms of $\mathrm{Cx} 43$}

mRNAs from $n e u^{-}$and $n e u^{+}$cells were subjected to Northern blot analyses (Fig. 4, lanes 1-3). Both cell lines revealed high levels of Cx43 mRNA, with the $n e u^{+}$cells having a significantly higher relative level, about two times more when identical amounts of mRNA (20 $\mu \mathrm{g}$ as determined from ethidium bromide staining) were compared by densitometry. We also checked for the expression of various other connexin mRNAs (Cx26, Cx32, Cx37, and Cx40), which have previously been described to be expressed in brain tissues (Dermietzel et al., 1989; Willecke et al., 1991; Hennemann et al., 1992). No mRNAs for these connexins were found either in the wild-type or in the C-erbB2/neu transfected cells (not shown). 
Figure 4. Northern blot analysis and in situ hybridization of $\mathrm{Cx} 43$ mRNA. Cx43 mRNA revealed high levels in $\mathrm{neu}^{-}$(2) and $\mathrm{neu}^{+}$(3) cells. Lane 1 shows RNA isolated from heart as a positive control. In situ hybridization using an antisense DNA probe for $\mathrm{Cx} 43$ labeled with digoxigenin revealed intense cytoplasmic labeling of $\mathrm{Cx} 43 \mathrm{RNA}$ in neu cells $(A)$ as well as $n e u^{+}$cells $(B)$.

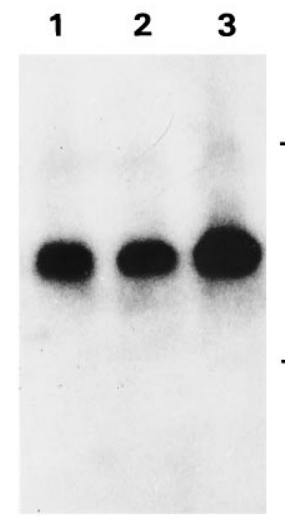

In situ hybridization using a $1.3 \mathrm{~kb}$ cDNA of $\mathrm{Cx} 43$ (see Beyer et al., 1987) showed a dispersed cytoplasmic distribution of the transcript in both cell types (Fig. 4A,B). Control experiments were performed by omitting the cDNA in the hybridization mixture and by prehybridization of the sections with an unlabeled antisense RNA, which was transcribed from the linearized cDNA. Both controls were negative with respect to $\mathrm{Cx} 43 \mathrm{mRNA}$ labeling (not shown).

We next examined expression of $\mathrm{Cx} 43$ protein because the presence of the mRNA does not necessarily indicate translation into its gene product. Western blot analyses of neu ${ }^{-}$cell homogenates using two site-specific antibodies directed to position 346360 (pAb1) and position 359-381 (pAb2) of $\mathrm{Cx} 43$ revealed a triplet of bands at positions 40,43 , and $45 \mathrm{kDa}$, which, according to Musil et al. (1990), represent the NP, $\mathrm{P}_{1}$, and $\mathrm{P}_{2}$ forms (Fig. 5, lane 3). Here we refer to this nomenclature, although in highresolution Western blots a fourth band around $41 \mathrm{kDa}$ was detectable (see Fig. 6), which according to Laird et al. (1991) represents a phosphorylated state of the nascent $40 \mathrm{kDa}$ form that is associated with the Golgi apparatus. In the $n e u^{+}$cells, the upper two bands (i.e., at position 43 and $45 \mathrm{kDa}$ ) were missing (Fig. 5,

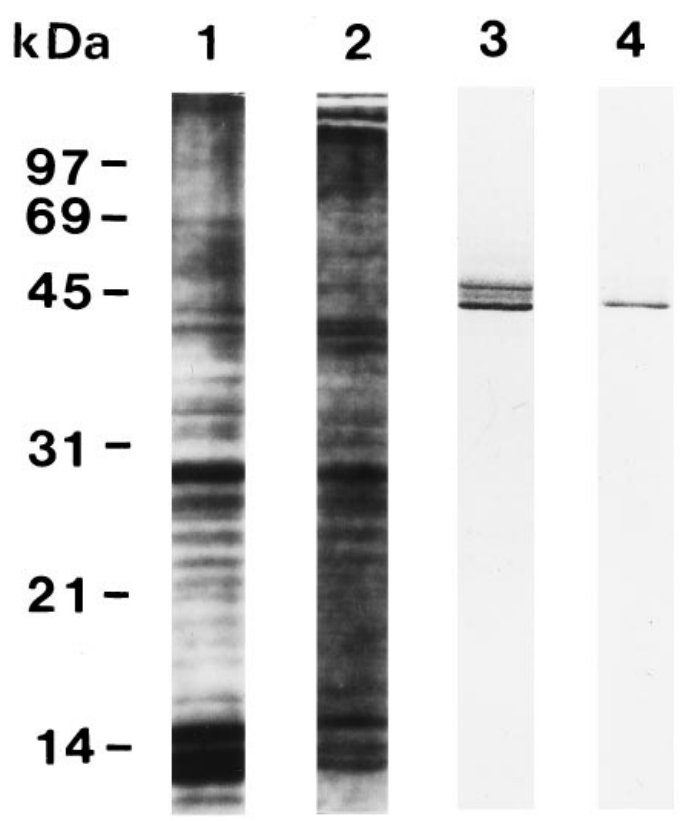

Figure 5. SDS-PAGE and Western blot analyses of neu (lanes 1 and 3) and $\mathrm{neu}^{+}$(lanes 2 and 4) cells. Western blots of neu $u^{-}$cell homogenates (3) revealed a triplet of bands (41, 43, and $45 \mathrm{kDa}$, see lane 3$)$, whereas only a $41 \mathrm{kDa}$ band was detected in $n e u^{-}$cells (4).

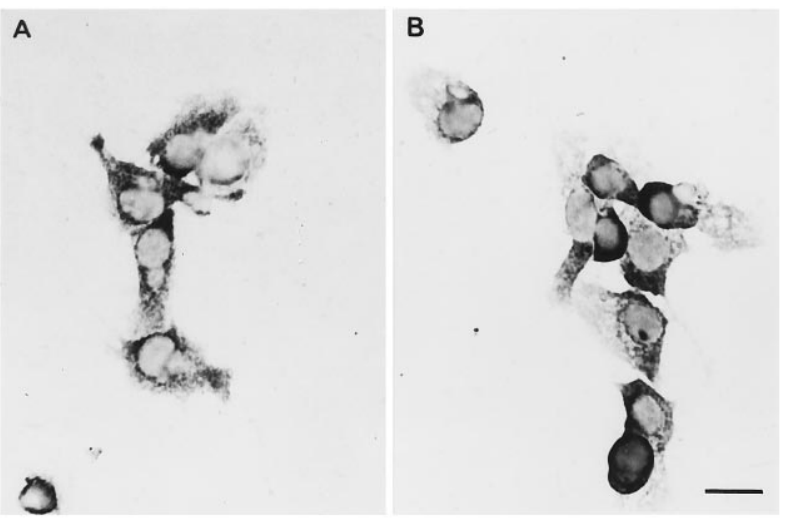

lane 4). These data indicated a loss of the less mobile isoforms of Cx43 in the $n e u^{+}$cells. The isoforms have been repeatedly shown to represent different states of phosphorylation of the Cx43 protein (Musil et al., 1990; Laird et al., 1991; Lau et al., 1991; Berthoud et al., 1992).

To obtain information regarding the subcellular distribution and differences in processing of the $\mathrm{Cx} 43$ isoforms, we performed subfractionation of both cell lines. In the $n e u^{-}$cells, all $\mathrm{Cx} 43$ forms were equally abundant in the membrane-containing subfractions corresponding to different cellular components (Fig. $6 A$ ), whereas in the $\mathrm{neu}^{+}$cells, a relative enrichment of the NP Cx43 species was present in the microsomal fraction (Fig. 6B, lane $c$ ) compared with the cell homogenate and crude membrane fraction (Fig. $6 B$, lanes $a, b$ ). This finding is suggestive of an enrichment of the NP form in the microsomal compartment of $n e u^{+}$cells. However, the total amount of the Cx43 proteins in the $n e u^{+}$cells appeared to be reduced compared with the $n e u^{-}$cells ( $\sim 50 \%$ when the three isoforms in the subfractions are scanned
A

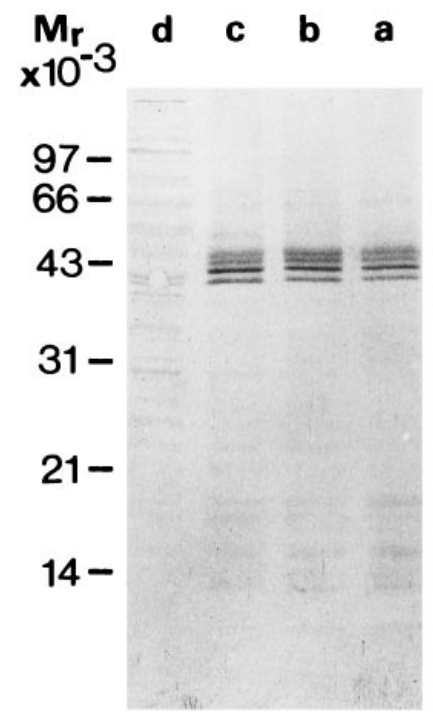

B

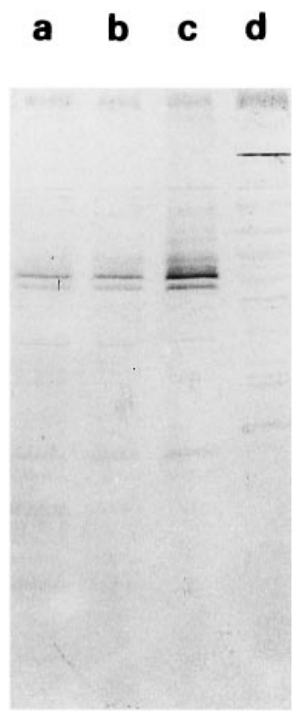

Figure 6. Western blots of subcellular fractions obtained from neu ${ }^{-}(A)$ and $\mathrm{neu}^{+}(B)$ cells. Blots are mounted in mirror symmetry. Besides the triplet of $\mathrm{Cx} 43$ bands commonly found for $\mathrm{Cx} 43$, an additional band at a position corresponding to $41 \mathrm{kDa}$ is visible, which according to Laird et al. (1991) represents the unphosphorylated Cx43 isoform. $a$, Cell homogenates; $b$, plasma membrane-enriched fraction; $c$, microsomal fraction; $d$, cytosolic fraction. In $\mathrm{neu}^{+}$cells, the NP isoform of Cx43 was relatively enriched in the microsomal fraction $(B$, lane $c)$. 


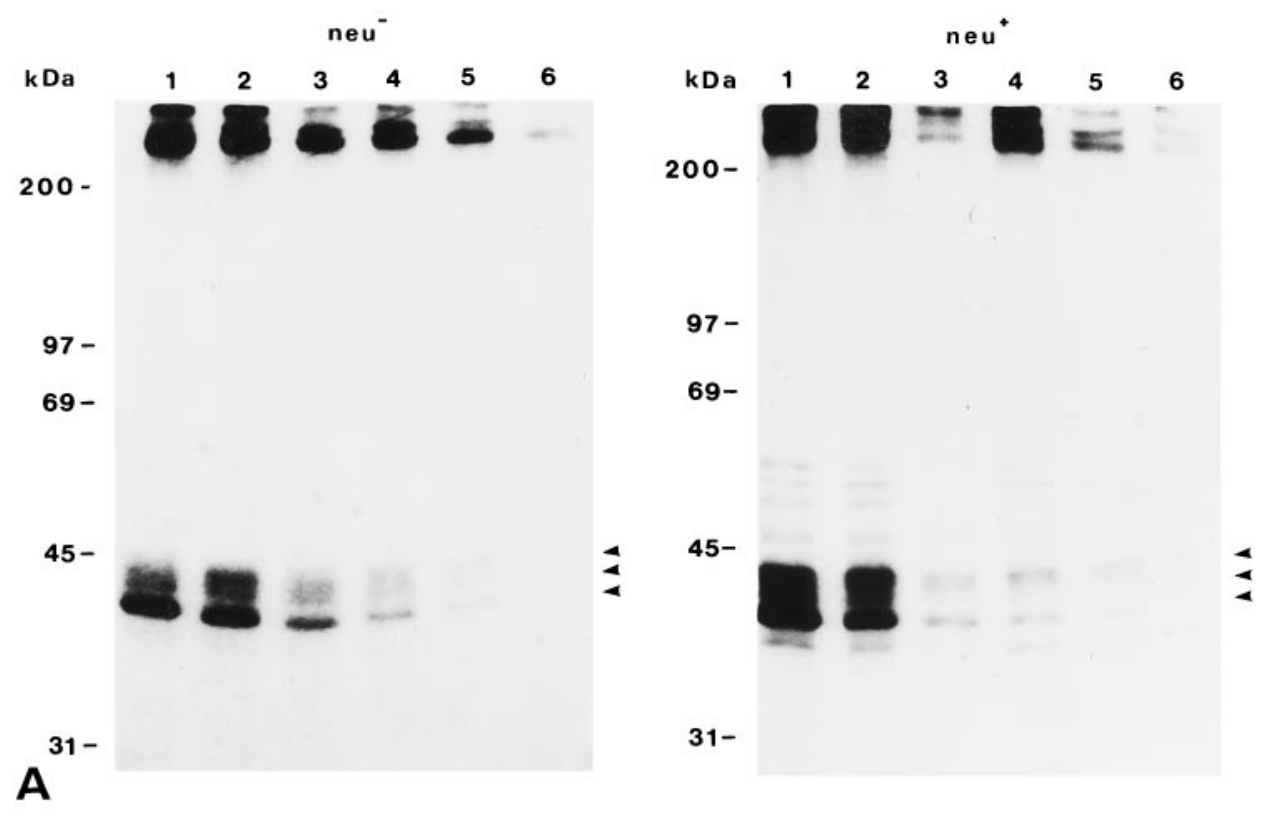

\section{half time of connexin 43}

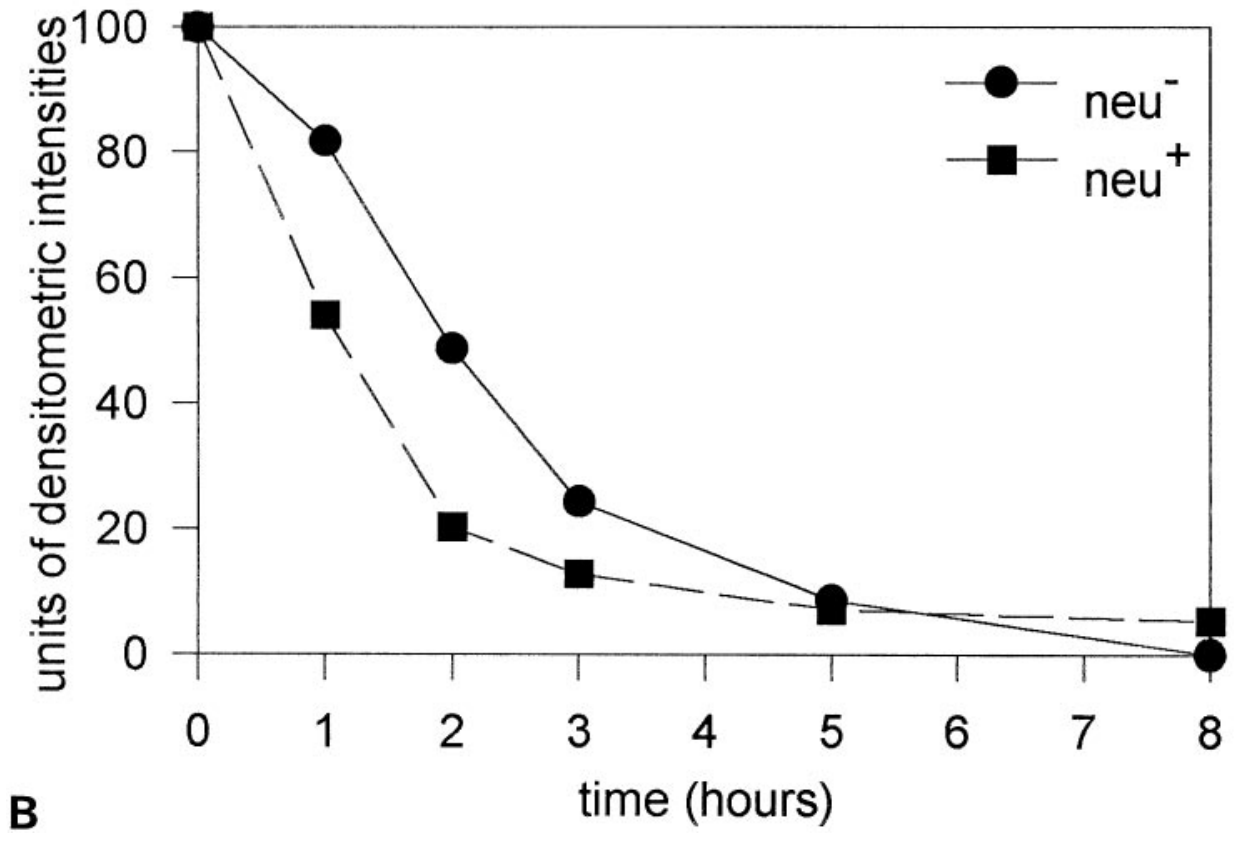

Figure 7. Half-life measurements of $\mathrm{Cx} 43$ protein in $n e u^{-}$and $n e u^{+}$cells. A, Autoradiograms of immunoprecipitated $\mathrm{Cx} 43$ after pulse chase. Cell lines were labeled with $\left.{ }^{35} \mathrm{~S}\right]$ methionine for $7 \mathrm{hr}$ and cultivated for various durations in medium with unlabeled methionine (lanes 1-6 correspond to 0, 1, 2, 3, 5, and $8 \mathrm{hr}$ ). Arrows indicate the three phosphorylated isoforms of $\mathrm{Cx} 43$. After separation of the precipitates on SDS gels, the gels were processed for fluorography and exposed for 3 weeks to X-ray films. Autoradiographs were digitized and standardized to maximal intensity. $B$, Diagram depicting the lifetime of $\mathrm{Cx} 43$ in neu ${ }^{-}$and $n е u^{+}$cells as taken from the autoradiograms. The indicated values represent the densitometrically measured mean values of three independent experiments. The half-time of the $41 \mathrm{kDA}$ isoform of $\mathrm{Cx} 43$ is between 1 and 3 $\mathrm{hr}$ for both cell lines.

by densitometry). One reason for a reduction, besides inhibitory effects on translational and/or post-translational regulatory mechanisms, could be an enhanced degradation of the Cx43 under the influence of the oncogene. We therefore checked for the half-time of the $\mathrm{Cx} 43$ protein in $n e u^{-}$and $n e u^{+}$cells. Pulse-chase experiments on both cell lines indicated a half-time of $\sim 2-4 \mathrm{hr}$ of the $\mathrm{Cx} 43$ protein, revealing no differences in the overall turnover of the $\mathrm{Cx} 43$ protein (Fig. $7 A, B$ ). Thus, an influence of the oncogene on the survival rate of the protein seems highly unlikely. A more trivial explanation of the apparent reduction of $\mathrm{Cx} 43$ in the $n e u^{+}$ cells is that the relative ratio of $\mathrm{Cx} 43$ to the total amount of protein loaded on the gels for Western blotting (20 $\mu \mathrm{g}$ per lane) decreased because the $n e u^{+}$cells overexpress the oncogene product. We therefore checked the amount of protein per cell, which gave an approximate concentration of $0.45 \pm 0.3 \mathrm{ng}(n=2)$ for $n e u^{-}$and $0.46 \pm 0.2 \mathrm{ng}(n=2)$ for $n e u^{+}$, indicating no significant difference in overall protein concentration. This finding renders the notion of a relative reduction of $\mathrm{Cx} 43$ concentration attributable to a simple shift in protein ratios unlikely.

Differences in Cx43 phosphorylation were confirmed by metabolic labeling of wild-type cells and neu-transformed cells with $\left[{ }^{32} \mathrm{P}\right]$ orthophosphate for $4 \mathrm{hr}$ followed by immunoprecipitation with anti-Cx43 (pAb2) antibody (Fig. 8A). Approximately 50\% less ${ }^{32}$ P-labeled Cx43 was immunoprecipitated from $\mathrm{neu}^{+}$compared with $n e u^{-}$. We also examined the phosphoamino acid content of ${ }^{32} \mathrm{P}$-labeled $\mathrm{Cx} 43$ in the $n e u^{-}$and $n e u^{+}$cells. Immunoprecipitates of $\left[{ }^{32} \mathrm{P}\right]$ phosphate-labeled $\mathrm{Cx} 43$ were separated using SDS-PAGE. Gel pieces corresponding to the Cx43 bands 


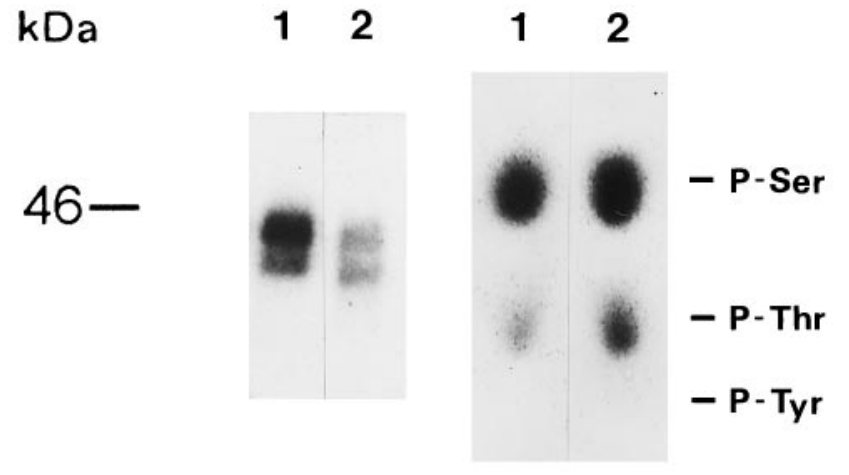

A

B
Figure 8. A, Phosphorylation and immunoprecipitation of Cx43 in neu(lane 1) and $\mathrm{neu}^{+}$(lane 2) cells. $\mathrm{Neu}^{+}$cells produced $\sim 50 \%$ less phosphorylated $\mathrm{Cx} 43$ than $n e u^{-}$cells. $B$, Phosphoamino acid analysis of $\mathrm{Cx} 43$ from $n e u^{-}(1)$ and $n e u^{+}(2)$ cells: $n e u^{-}$and $n e u^{+}$cells revealed phosphoserine and phosphothreonine but not phosphotyrosine. Positions of the ninhydrin-stained unlabeled phosphoserine, phosphothreonine, and phosphotyrosine standards are indicated.

were obtained and processed as described in Materials and Methods. $\mathrm{Cx} 43$ proteins eluted from the gel pieces were subjected to acid hydrolysis and phosphoamino acids were separated by thinlayered electrophoresis. No phosphotyrosine was detected in either case. Cx43 from both $\mathrm{neu}^{-}$and $n e u^{+}$cells was predominantly phosphorylated in serine and, to a minor extent, in threonine residues (Fig. 8B). Nonetheless, the relative amount of phosphothreonine detected in $\mathrm{Cx} 43$ from $\mathrm{neu}^{+}$was higher than that of $n e u^{-}$cells. The apparent higher radioactivity seen in the neu ${ }^{+}$ sample that incorporates less ${ }^{32} \mathrm{P}$ under immunoprecipitation conditions (Fig. $8 A$ ) can be explained because similar amounts of radiolabeled material was used for phosphoamino acids analysis of Cx43 from neu ${ }^{-}$and $n e u^{+}$cells.

\section{C-erbB2/neu cells reveal disturbance of trafficking of $\mathrm{Cx} 43$}

The intracellular distribution of $\mathrm{Cx} 43$ immunoreactivity in both $n e u^{-}$and $n e u^{+}$cell lines was also examined by indirect immunofluorescence. Immunolabeling with $\mathrm{Cx} 43$ antibodies showed a pattern of discrete staining at adjacent membranes in the form of spots or linear fluorescence with some vesicular intracytoplasmic immunoreactivity in the $n e u^{-}$cells. This pattern contrasted markedly with the staining pattern found in the new transfected cell line. In the latter, diffuse intracytoplasmic labeling occurred without any visible gap junction plaque formation in the plasma membrane which, under conventional light microscopical conditions, could not be further resolved with respect to its subcellular distribution (Fig. 9a,b). To obtain resolution at the subcellular level, we performed confocal scanning laser microscopy, which allows the definition of immunoreactivity at precise confocal sections of single cells or cell clusters. A series of such confocal sections of the $n e u^{-}$cells compared with the transfected cell line is indicated in Figure $9 A-D$. From inspection of the confocal images, it becomes evident that macular plasmalemmal immunoreactivity at different levels of the adjoining cells is exclusively present in the $n e u^{-}$cells (Fig. $9 A-D$ ). However, the transfected cells also revealed plasma membrane staining. This staining was diffusely distributed at the interfaces between the cells, without aggregation of the immunolabel to typical gap junction plaques (Fig. $9 A^{\prime}-D^{\prime}$ ). The results suggest that in the $n e u^{+}$cells, unlike the $n e u^{-}$cells, $\mathrm{Cx} 43$ does not accumulate to gap junction assemblies within the plasma membrane. Cytoplasmic staining was also present in form of single vesicles and in juxtanuclear regions. The juxtanuclear staining was more pronounced in the C-erbB2/neu transfected cells (Fig. 9 $A^{\prime}, B^{\prime}$ ). A similar observation has been made with C-erbB2/neu transfected rat liver epithelial cells (Jou et al., 1995).

\section{Transformation with C-erbB2/neu leads to N-CAM deficiency in glial cells}

$\mathrm{Neu}^{+}$cells showed a remarkable reduction in cell adhesion and cell spreading (see above). In recent reports, it has been shown that CAM expression is crucial for establishment of functional gap junctions in different cell lines (Musil et al., 1990; Meyer et al., 1992). Lack of L-CAM has also been correlated with communication deficiency and inability of $\mathrm{Cx} 43$ to be phosphorylated to the less mobile protein isoforms (Musil et al., 1990). We therefore checked the $n e u^{-}$and $n e u^{+}$cells for the presence of N-CAM with a polyclonal antiserum that detects $\mathrm{N}-\mathrm{CAM}$ on glial cells (Faissner et al., 1984). Immunofluorescence (Fig. 10A,B) as well as Western blots (Fig. 10C) indicated that $n e u^{+}$cells are devoid of $\mathrm{N}-\mathrm{CAM}$ expression. Comparison of primary cultured astrocytes and $n e u^{-}$cells with the $n e u^{+}$transfectants clearly showed a lack of the two dominant isoforms of the N-CAM, which display relative masses of 120 and $150 \mathrm{kDa}$ in the $\mathrm{neu}^{-}$cell line (Fig. 10C, lane 3).

\section{DISCUSSION}

Gap junction communication appears to be essential for the syncytial behavior of astrocytes, because these channels provide the structural link that couples individual cells and thereby allows coordination of simultaneously occurring functions (for recent review, see Dermietzel and Spray, 1993). The coordinating properties of gap junctions have been suggested to include such basic cell biological functions as differentiation, cell growth, and synchronization of various cellular activities, i.e., contraction of smooth muscle and cardiac myocytes (Spray et al., 1994), secretion of epithelial and endocrine cells (Yamamoto and Kataoka, 1988; Meda et al., 1993), and synchronization of neuronal activity (Conners et al., 1983; Kessler et al., 1985; Llinás, 1985). The high degree of gap junction presence and functional coupling between astrocytes (Dermietzel et al., 1991) allows the direct exchange of information essential for the coordinated behavior of the astrocytic syncytium.

The recent documentation of $\mathrm{Ca}^{2+}$ waves by topical glutamate application or mechanical stimulation (Cornell-Bell et al., 1990) and its sensitivity to the gap junction inhibitor heptanol (Finkbeiner, 1992) is a clear demonstration of the gap junctional coupling efficiency between astrocytes. The coordinated properties of the coupled astrocytic syncytium is likely to be subject to functional modifications requiring dynamic capabilities. Modulation of astrocytic coupling has been demonstrated at the level of dye coupling, where norepinephrine and endothelins led to rapid decoupling in cultured astrocytes (Giaume et al., 1991b; Giaume et al., 1992). In situ modulation of $\mathrm{Cx} 43$ in response to exogenous stimulation has also recently been reported. For instance, intracerebral kainic acid alters accessibility to $\mathrm{Cx} 43$ antiserum (Vukelic et al., 1991; Hossain et al., 1994), and ligation of the facial nerve leads to a rapid upregulation of $\mathrm{Cx} 43$ expression in the corresponding nuclei in the brainstem (Rohlmann et al., 1993). The latter event seems to occur as an early response $(<1.5 \mathrm{hr}$; Rohlmann et al., 1994), indicating rapid regulation of Cx43 expression in astrocytes. 
Coupling efficiency can be modulated at different levels, includes transcriptional and translational regulation sites as well as posttranslational events such as phosphorylation of the protein, trafficking, membrane insertion, and assembly into functional gap junction plaques. It has been suggested that $\mathrm{Cx} 43$ phosphorylation might be a crucial step in the assembly of functionally competent gap junction plaques (Musil and Goodenough, 1991). Our findings in C-erbB2/ neu transfected glial cells allow extrapolation of these data originally obtained from mouse sarcoma cell lines to astrocytes. Communication-deficient $\mathrm{neu}^{+}$glial cells consistently showed a reduction of the higher phosphorylated $\mathrm{Cx} 43$ species compared with the $n e u^{-}$cells. Unlike the effect of the $\mathrm{pp} 60^{\mathrm{v}-\mathrm{src}}$ oncogene product (Swenson et al., 1990), the coupling deficiency induced by C-erbB2/ neu transfection is not related to tyrosine phosphorylation of $\mathrm{Cx} 43$. A further difference from transformation by $\mathrm{pp} 60^{\mathrm{v}-\mathrm{src}}$, which leads to an elevation of Cx43 in Rat 1 fibroblasts (Goldberg and Lau, 1993), is the apparent reduction of total $\mathrm{Cx} 43$ in our glial cell line after $\mathrm{C}$-erbB2/neu transfection. As already indicated, a simple explanation of this effect attributable to a shift of protein concentration by oncogene expression seems unlikely. We therefore consider that, in addition to the inhibition of phosphorylation (see below), the C-erbB2/neu oncogene may influence on the post-translational biosynthetic pathway of $\mathrm{Cx} 43$.

From the confocal imaging of the $n e u^{+}$cells, it is apparent that the major effect of the transfection on $\mathrm{Cx} 43$ distribution is in plaque assembly rather than the insertion of $\mathrm{Cx} 43$ into the plasma membrane. Because of the marked depletion in more highly phosphorylated isoforms of $\mathrm{Cx} 43$ in these cells, we conclude that the final step in junctional assembly in astrocytes depends on accurate phosphorylation of the junctional protein. The residual transfer of $\mathrm{Ca}^{2+}$ that we found in the $n e u^{+}$cells can be explained simply as a random distribution of small clusters of channels, which may provide sufficient junctional conductance to permit $\mathrm{Ca}^{2+}$ passage.

Assembly of gap junction plaques apparently requires close cell-to-cell apposition. In a number of experiments, it has been shown that cell adhesion molecules are involved in establishment of cell-to-cell communication. Lack of L-CAM expression correlates with communication deficiency in sarcoma cell lines (Musil et al., 1990), and ordinarily communication-competent cells could be converted to communication-defective cells by exposure to anti-A-CAM antibodies (Meyer et al., 1992). Re-establishment of communication by transfection with a specific cDNA encoding the cell-cell adhesion molecule L-CAM corrected both the Cx43 phosphorylation deficiency and restored junctional communication (Mage et al., 1988; Musil et al., 1990; Jongen et al., 1991). The data suggest a functional link between gap junction formation and strong cell-cell association via CAM proteins. The inability of the $\mathrm{neu}^{+}$cells to establish appropriate gap junctions also seems correlated with the proper expression of N-CAM, because neu transfection resulted in a loss of expression of this cell adhesion
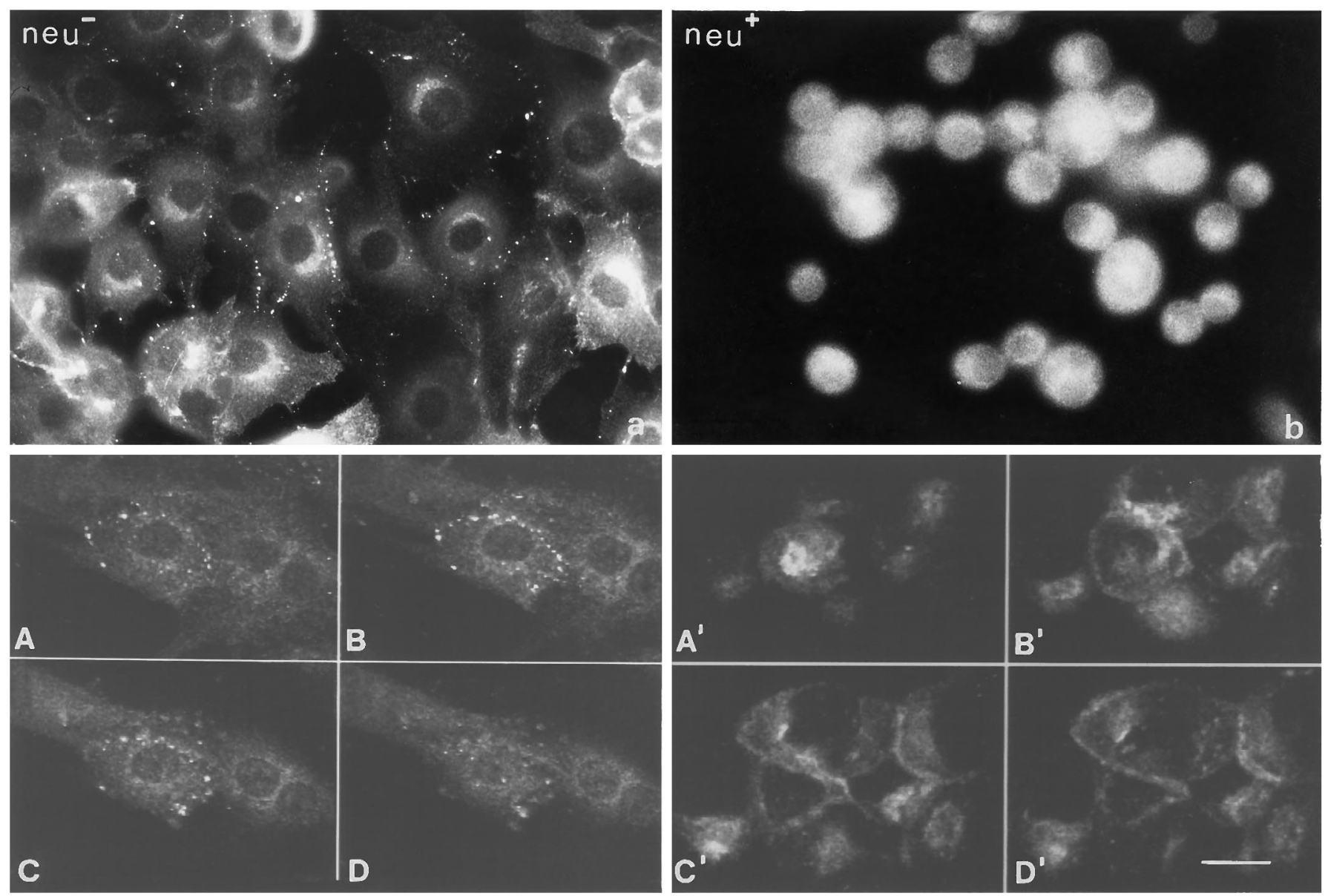

Figure 9. Immunocytochemical detection of $\mathrm{Cx} 43$ in $n e u^{-}$and $n e u^{+}$cells. $a, b$, Immunolabeling showed a pattern of discrete punctate staining at adjacent cell membranes in $n e u^{-}$cells $(a)$ and diffuse intracytoplasmic labeling in $n e u^{+}$cells $(b) . A-D^{\prime}$, Confocal scanning laser microscopy of anti-Cx43-labeled cells. Plaque-like plasmalemmal staining and some juxtanuclear staining is evident in $n e u^{-}$cells $(A-D)$, whereas $n e u^{+}$cells $\left(A^{\prime}-D^{\prime}\right)$ reveal diffuse membrane and juxtanuclear staining without any plaque-like formations. Scale bar, $20 \mu \mathrm{m}$. 
Figure 10. Immunofluorescence $(A, B)$ and immunohistochemical detection $(C)$ of N-CAM. $A$ depicts well defined immunolabeling of the plasma membrane in $n e u^{-}$cells. $\mathrm{B}, \mathrm{Neu}^{+}$cells are devoid of anti-N-CAM immunoreactivity above background levels of intracellular autofluorescence. Scale bar, 20 $\mu \mathrm{m}$. $C$, Western blots of homogenates of cultured astrocytes (lane 1), neu ${ }^{-}$(lane 2), and neu $^{+}$(lane 3 ) cells using an anti-N-CAM antibody. Bands at the two major isoforms of $\mathrm{N}-\mathrm{CAM}$ at positions 120 and $150 \mathrm{kDa}$ for primary astrocytes (lane 1) and wild-type cells (neu ${ }^{-}$; lane 2, arrows); no bands are found at corresponding positions in the $\mathrm{neu}^{+}$cells (lane 3). Scale bar, $20 \mu \mathrm{m}$.
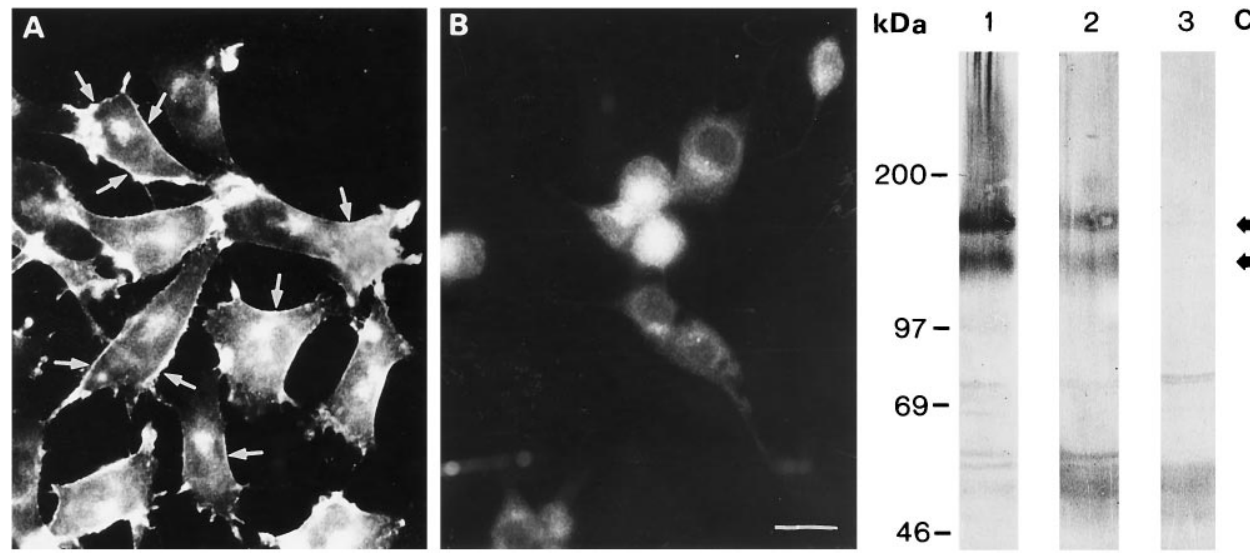

molecule. Thus, a scenario seems feasible by which activation of protein kinase activities are modulated directly by adhesion molecules, or indirectly, through signal transduction proteins. It is important to point out that the correlation that we and others have observed between $\mathrm{Cx} 43$ phosphorylation and gap junction assembly is not the only effect of phosphorylation on gap junction function. Biophysical properties of the Cx43 channel depend on its phosphorylation state, with an increase in unitary conductance and more rapid kinetics of closure by transjunctional voltage after dephosphorylation (Moreno et al., 1992, 1994). A possible link between changes in phosphorylation and physiological status of the cell has recently been shown by Lau et al. (1992), who provided evidence that epidermal growth factor (EGF) can transiently disrupt gap junctional communication. This effect correlates with an increase in $\mathrm{Cx} 43$ phosphorylation mainly in serine residues and not in tyrosine residues as might have been expected, because EGF receptor has an intrinsic tyrosine kinase activity (Yarden and Ullrich, 1988). In this process, phosphorylation of Cx43 serine residues is induced, perhaps attributable to microtubule-associated protein (MAP) kinase activity (Lau et al., 1992; Kanemitsu and Lau, 1993) or other serine/threonine kinases. The phosphorylation site of MAP kinase is independent from that of TPA-induced protein kinase $\mathrm{C}$ serine phosphorylation, which also disrupts junctional communication in at least some cell types (Brissette et al., 1991) presumably by inducing differential phosphorylation of serine residues of $\mathrm{Cx} 43$ (Berthoud et al., 1993). The regulation of gap junctional intercellular communication seems to involve multisite phosphorylation orchestrated by a complex interplay of intracellular protein kinases, thereby working on distinct levels of Cx43 biosynthesis. From further studies of this interplay, including the assembly mechanism of gap junction plaques, we expect to obtain a more complete understanding of the plasticity of the astrocytic network under normal conditions and in situations of pathological stress.

\section{REFERENCES}

Azarnia R, Loewenstein WR (1987) Polyomavirus middle T antigen downregulates junctional cell-to-cell communication. Mol Cell Biol 7:946-950.

Bargmann CI, Hung M-C, Weinberg RA (1986a) Multiple independent activations of the neu oncogene by a point mutation altering the transmembrane domain of p185. Cell 45:649-657.

Bargmann CI, Hung M-C, Robert AW (1986b) The neu oncogene encodes an epidermal growth factor receptor-related protein. Nature 319:226-230.

Barres BA, Chun LLY, Crey DP (1990) Ion channels in vertebrate glia. Annu Rev Neurosci 13:441-474.
Bennett MVL, Barrio TA, Bargiello TA, Spray DC, Hertzberg E, Sáez JC (1991) Gap junctions: new tools, new answers, new questions. Neuron 6:305-320.

Berthoud VM, Ledbetter ML, Hertzberg EL, Sáez JC (1992) Connexin43 in MDCK cells: regulation by a tumor promoting phorbol ester and $\mathrm{Ca}^{2+}$. Eur J Cell Biol 57:40-50.

Berthoud VM, Rook MB, Traub O, Hertzberg EL, Sáez JC (1993) On the mechanism of cell uncoupling induced by a tumor promotor phorbol ester in clone 9 cells a rat liver epithelial cell line. Eur J Cell Biol 62:384-396.

Beyer EC (1993) Gap junctions. Int Rev Cytol 137C:1-37.

Beyer EC, Paul DL, Goodenough DA (1987) Connexin43: a protein from rat heart homologous to a gap junction protein from liver. J Cell Biol 105:2621-2629.

Bignami M, Rosa S, Falcone G, Tato F, Katoh F, Yamasaki H (1988) Specific viral oncogenes cause differential effects on cell-to-cell communication, relevant to the suppression of the transformed phenotype by normal cells. Mol Carcinog 1:67-75.

Brissette JL, Kumar NM, Gilula NB, Dotto GP (1991) The tumor promoter 12-O-tetradecanoylphorbol-13-acetate and the ras oncogene modulate expression and phosphorylation of gap junction proteins. Mol Cell Biol 1:5364-5371.

Caspar DLC, Goodenough DA, Makowski L, Phillips WC (1977) Gap junction structures. I. Correlated electron microscopy and X-ray diffraction. J Cell Biol 74:605-628.

Conners BW, Bernardo LS, Prince DA (1983) Coupling between neurons of the developing rat neocortex. J Neurosci 3:773-782.

Cornell-Bell AH, Finkbeiner SM, Cooper MS, Smith SJ (1990) Glutamate induces calcium waves in cultured astrocytes: long-range glial signaling. Science 247:470-473.

Coussens L, Yang-Feng TL, Chen Y-CLE, McGrath J, Seeburg PA, Libermann TA, Schlessinger J, Francke U, Levinson A, Ullrich A (1985) Tyrosine kinase receptor with extensive homology to EGF receptor shares chromosomal location with neu oncogene. Science 230:1132-1139.

Dermietzel R, Spray DC (1993) Gap junctions in the brain: where, what type, how many and why? Trends Neurosci 16:186-192.

Dermietzel R, Leibstein A, Frixen U, Janssen-Timmen U, Traub O, Willecke K (1984) Gap junctions in several tissues share antigenic determinants with liver gap junctions. EMBO J 3:2261-2270.

Dermietzel R, Traub O, Hwang TK, Beyer E, Bennett MVL, Spray DC, Willecke K (1989) Differential expression of three gap junction proteins in developing and mature brain tissue. Proc Natl Acad Sci USA 86:10148-10152.

Dermietzel R, Hertzberg EL, Kessler JA, Spray DC (1991) Gap junctions between cultured astrocytes: immunocytochemical, molecular, and electrophysiological analysis. J Neurosci 11:1421-1432.

Dermietzel R, Krause D, Kremer M, Wang C, Stevenson B (1992) Pattern of glucose transporter (Glu1) expression in embryonic brains is related to maturation of blood brain barrier tightness. Dev Dyn 193:152-163.

Dotto GP, el-Fouly MH, Nelson C, Trosko JE (1989) Similar and synergistic inhibition of gap-junctional communication by ras transformation and tumor promoter treatment of mouse primary keratinocytes. Oncogene 4:637-641. 
Faissner A, Kruse J, Goridis C, Bock E, Schachner M (1984) The neural cell adhesion molecule L1 is distinct from the N-CAM-related group of surface antigens BSP-2 and D2. EMBO J 3:733-737.

Finkbeiner S (1992) Calcium waves in astrocytes-filling in the gaps. Neuron 8:1101-1108.

Gardner-Melvin AR (1983) Analysis of potassium dynamics in mammalian brain tissue. J Physiol (Lond) 336:393-549.

Giaume C, Fromaget C, El Aoumari A, Cordier J, Glowinski J, Gros D (1991a) Gap junctions in cultured astrocytes: single-channel currents and characterization of channel-forming protein. Neuron 6:133-143.

Giaume C, Marin P, Cordier J, Glowinski J, Premont J (1991b) Adrenergic regulation of intercellular communication between cultured striatal astrocytes from the mouse. Proc Natl Acad Sci USA 88:5577-5581.

Giaume C, Cordier J, Glowinski J (1992) Endothelins inhibit junctional permeability in cultured mouse astrocytes. Eur J Neurosci 4:877-881.

Goldberg GS, Lau AF (1993) Dynamics of connexin43 phosphorylation in pp60 ${ }^{\text {v-src }}$-transformed cells. Biochem J 295:735R-740R.

Hennemann H, Suchyna T, Lichtenberg-Frat H, Jungbluth S, Dahl E, Schwarz H-J, Nicholson BJ, Willecke K (1992) Molecular cloning and functional expression of mouse connexin40, a 2nd gap junction gene preferentially expressed in lung. J Cell Biol 117:1299-1310.

Hossain MZ, Sawchuk MA, Murphy LJ, Hertzberg EL, Nagy JI (1994) Kainic acid induced alteration in antibody recognition of connexin 43 and loss of astrocytic gap junctions in rat brain. Glia 10:250-265.

Jongen WM, Fitzgerald DJ, Asamoto M, Piccoli C, Slaga TJ, Gros D, Takeichi M, Yamasaki H (1991) Regulation of connexin43-mediated gap junctional intercellular communication by $\mathrm{Ca}^{2+}$ in mouse epidermal cells is controlled by E-cadherin. J Cell Biol 114:545-555.

Jou YS, Lahe B, Matesic DF, Chang CC, de Feijter AW, Lockwood L, Welsch CW, Klaunig JE, Trosko JE (1995) Inhibition of gap junctional intercellular communication and malignant transformation of rat liver epithelial cells by neu oncogene. Carcinogenesis 16:311-317.

Kanemitsu MY, Lau AF (1993) Epidermal growth factor stimulates the disruption of gap junctional communication and connexin 43 phosphorylation independent of 12-O-tetradecanoylphorbol 13-acetate-sensitive protein kinase $\mathrm{C}$ : the possible involvement of mitogen-activated protein kinase. Mol Biol Cell 4:837-848.

Kessler JA, Spray DC, Sáez JC, Bennett MVL (1985) Development and regulation of eletrotonic coupling between sympathetic neurons. In: Gap junctions. (Bennett MVL, Spray DC, eds), pp 231-240. Cold Spring Harbor, NY: Cold Spring Harbor Laboratories.

Kuffler SW, Nicholls JG, Orkand RK (1966) Physiologic properties of glial cells in the central nervous system of amphibia. J Neurophysiol 29:768-787.

Laemmli UK (1970) Cleavage of structural proteins during the assembly of the head of bacteriophage T4. Nature 227:680-685.

Laird DW, Puranam KL, Revel J-P (1991) Turnover and phosphorylation dynamics of connexin43 gap junction protein in cultured cardiac myocytes. Biochem J 273:67-72.

Lau AF, Hatchpigott V, Crow DS (1991) Evidence that heart connexin43 is a phosphoprotein. J Mol Cell Cardiol 23:659-663.

Lau AF, Kanemitsu MY, Kurata WE, Danesh S, Boynton AL (1992) Epidermal growth factor disrupts gap-junctional communication and induces phosphorylation of connexin43 on serine. Mol Biol Cell 3:865-874.

Llinás RR (1985) Electronic transmission in the mammalian central nervous system. In: Gap junctions (Bennett MVL, Spray DC, eds). Cold Spring Harbor, NY: Cold Spring Harbor Laboratory.

Lowry DH, Rosebrough NJ, Farr AL, Randall RJ (1951) Protein measurement with the Folin phenol reagent. J Biol Chem 193:265-275.

Mage RM, Matsuzaki F, Gallin WJ, Goldberg JI, Cunningham BA, Edelman GM (1988) Construction of epithelioid sheets by transfection of mouse sarcoma cells with cDNAs for chicken cell adhesion molecules. Proc Natl Acad Sci USA 85:7274-7278.

Makowski L, Caspar DL, Phillips WC, Goodenough DA (1977) Gap junction structures. II. Analysis of the X-ray diffraction data. J Cell Biol 74:629-645.

Martin W, Zempel G, Huelser D, Willecke K (1991) Growth inhibition of oncogene transformed rat fibroblasts by cocultured normal cells: relevance of metabolic cooperation mediated by gap junctions. Cancer Res 51:5348-5354.

Meda P, Pepper MS, Traub O, Willecke K, Gros D, Beyer E, Nicholson B, Paul D, Orci L (1993) Differential expression of gap junction connexins in endocrine and exocrine glands. Endocrinology 133:2371-2378.
Meyer RA, Laird DW, Revel J-P, Johnson RG (1992) Inhibition of gap junctions and adherens junction assembly by Connexin and A-CAM antibodies. J Cell Biol 119:179-189.

Moreno AP, Fishman GI, Spray DC (1992) Phosphorylation shifts unitary conductance and modifies voltage dependent kinetics of human connexin43 gap junction channels. Biophys J 62:51-53.

Moreno AP, Sáez JC, Fishman GI, Spray DC (1994) Human connexin43 gap junction channels regulation of conductances by phosphorylation. Circ Res 74:1050-1057.

Musil LS, Cunningham BA, Edelmann GM, Goodenough DA (1990) Differential phosphorylation of the gap junction protein connexin 43 in junctional communication-competent and -deficient cell lines. J Cell Biol 111:2077-2088.

Musil LS, Goodenough DA (1991) Biochemical analysis of connexin43 intracellular transport, phosphorylation, and assembly into gap junctional plaques. J Cell Biol 115:1357-1374.

Newman EA (1986) High potassium conductance in astrocyte endfeet. Nature 233:453-454.

Orkand RK, Nicholls JG, Kuffler SW (1966) Effect of nerve impulses on the membrane potential of glial cells in the central nervous system of amphibia. J Neurophysiol 29:788-806.

Parpura V, Basarsky TA, Liu F, Jeftinija K, Jeftinija S, Haydon GP (1994) Glutamate-mediated astrocyte-neuron signalling. Nature 369:744-747.

Rohlmann A, Laskawi R, Hofer A, Dobo E, Dermietzel R, Wolff JR (1993) Facial nerve lesions lead to increased immunostaining of the astrocytic gap junction protein (connexin 43) in the corresponding facial nucleus of rats. Neurosci Lett 154:206-208.

Rohlmann A, Laskwi R, Hofer A, Dermietzel R, Wolff JR (1994) Astrocytes as rapid sensors of peripheral axotomy in the facial nucleus of rats. NeuroReport 5:409-412.

Sáez JC, Connor JA, Spray DC, Bennett MVL (1989) Hepatocyte gap junctions are permeable to the second messenger, inositol 1,4,5triphosphate, and to calcium ions. Proc Natl Acad Sci USA 86:2708-2712.

Sáez JC, Nairn AC, Czernik AJ, Spray DC, Hertzberg EL, Greengard P, Bennett MVL (1990) Phosphorylation of connexin32, a hepatocyte gap-junction protein, by cyclic AMP-dependent protein kinase, protein kinase $\mathrm{C}$ and calcium ion calmodulin-dependent protein kinase II. Eur J Biochem 192:263-274.

Sambrook J, Fritsch EF, Maniatis T (1989) Molecular cloning-a laboratory manual. Cold Spring Harbor, NY: Cold Spring Harbor Laboratory.

Spray DC, Rook M, Moreno AP, Sáez JC, Christ G, Campos de Carvallo AC, Fishman GI (1994) Gating properties, function and dysfunction. In: Ion channel in the cardiovascular system: function and dysfunction. (Spooner PM, Brown AM, Catterall WA, Kaczorowski GJ, Strauss HC, eds), pp 185-217. Mt Kisco: Futura.

Suter S, Trosko JE, el-Fouly MH, Lockwood LR, Koestner A (1987) Dieldrin inhibition of gap junctional intercellular communication in rat glia cells as measured by fluorescence photobleaching and scrape loading/dye transfer assays. Fundam Appl Toxicol 9:785-794.

Swenson KL, Piwnica-Worms H, McNamee H, Paul D (1990) Tyrosine phosphorylation of the gap junction protein connexin 43 is required for the pp60-v-src-induced inhibition of communication. Cell Regul 1:989-1002.

Thomas AP, Dellaville F (1991) The use of fluorescent indicators for measurements of cytosolic-free calcium concentration in cell populations and single cells. (McCormack JG, Cobbold PM, eds), pp 1-54. In: Cellular calcium: a practical approach. Oxford, UK: IRL.

Vukelic JI, Yamamoto T, Hertzberg EL, Nagy JI (1991) Depletion of connexin43-immunoreactivity in astrocytes after kainic acid-induced lesions in rat brain. Neurosci Lett 130:120-124.

Walz W (1989) Role of glial cells in the regulation of the brain ion microenvironment. Prog Neurobiol 33:309-333.

Willecke K, Heynkes R, Dahl E, Stutenkemper R, Hennemann H, Jungbluth S, Suchyna T, Nicholson BJ (1991) Mouse connexin37: cloning and functional expression of gap junction gene highly expressed in lung. J Cell Biol 114:1049-1057.

Yamamoto M, Kataoka K (1988) An electron microscope study of the development of the exocrine and endocrine pancreas with special reference to intercellular junctions. Arch Histol Cytol 51:315-325.

Yarden Y, Ullrich A (1988) Growth factor receptor tyrosine kinases. Annu Rev Biochem 57:443-478. 